\title{
SOSIALISASI DAN PENDAMPINGAN PENCEGAHAN PENYEBARAN COVID-19 DI PERUM TANGGAP COVID (PTC) AMERTA RESIDENCE RT 08/RW 05 DESA SAPTORENGGO
}

\author{
Nuril Hidayati ${ }^{1)}$, Trio Ageng Prayitno ${ }^{2)}$, Riyanto ${ }^{3)}$ \\ IKIP Budi Utomo \\ hidayatinuril20@gmail.com, trioageng@gmail.com*, riyanto.arkum.27.83@gmail.com
}

\begin{abstract}
Saptorenggo Village is declared as a Covid-19 red zone. However, the villagers, especially the residents of Perum Amerta Residence continue to engage in outdoor activities even some of them still work out of town. This behavior is a source of major problem in the distribution of Covid-19 at the Amerta Residence housing estate. A mutual agreement between the service team and the head of RT 08 and residents of the Amerta Residence housing estate to overcome the problem is needed so that the socialization and assistance in preventing the spread of Covid-19 can be performed. This type of activity is community service at the Amerta Residence RT 08 housing estate from March to June 2020. The procedure for community service activities consists of four stages including socialization through deliberations, the formation of the Perum Tanggap Covid (PTC) team, periodic disinfectant spraying assistance, and evaluation of community service activities. The results of this community service show that the community service team has succeeded in carrying out community service activities base on the planned targets. In addition, residents of Amerta Residence housing estate can follow all the service activities that have been designed by the service team.
\end{abstract}

Keywords: Covid-19; prevention; assistance; socialization

$\begin{array}{ccc}\text { Submit } & \text { Diterima } & \text { Dipublikasikan } \\ 28 \text { Juni } 2020 & \text { 30 Juli } 2020 & 31 \text { Juli } 2020\end{array}$

DOI : https://doi.org/10.33503/pambudi.v4i01.849

\section{ANALISIS SITUASI}

Amerta Residence RT 08/RW 05 terletak di Desa Saptorenggo. Sebuah desa yang masuk wilayah Kecamatan Pakis, Kabupaten Malang, Provinsi Jawa Timur, Indonesia. Batas sebelah timur Desa Saptorenggo adalah Desa Aslikaton, sebelah barat Desa Mangliawan, sebelah utara Desa Dengkol Singosari, dan sebelah selatan berbatasan dengan Desa Asrikaton (Saptorenggo, 2017). Letak Amerta Residence tidak jauh dari jalan raya utama. Akses Amerta Residence sangat mudah, yaitu jika lewat jalur udara bisa melalui Bandara Abdul Rachman Saleh (Abd. Shaleh) dan jika jalur darat dapat ditempuh dengan angkot karena tidak jauh dari terminal Arjosari atau menggunakan mobil pribadi bisa melalui Tol Pakis. Selain itu, jalan raya utama menuju Amerta Residence sangat dipadati oleh lalulalang mobil pribadi, transportasi umum, dan sepeda motor. Padatnya kendaraan di jalan raya utama itu dikarenakan banyak penduduk Kabupaten Malang yang bekerja ke Kota Malang dan banyaknya transportasi wisatawan yang ingin berwisata ke wisata Gunung Bromo-Semeru.

Jumlah penduduk yang tinggal di Amerta Residence RT 08 sebanyak 105 jiwa dari 40 Kepala Keluarga (KK) dan mayoritas merupakan pendatang bukan asli dari Malang. Jumlah penduduk laki-laki sebanyak 50 jiwa dan perempuan sebanyak 55 jiwa. Warga Amerta Residence memiliki mata pencaharian 
yang bervariasi. Ada yang berprofesi sebagai dosen, pengawai negeri pemkot Malang, polri, angkatan udara, tentara, perawat, bidan, pedagang dan wiraswasta. Mayoritas warga Amerta Residence bekerja ke Kota Malang. Mereka berangkat pagi dari kabupaten menuju kota untuk bekerja dan pulang kerja sore hari dari kota ke kabupaten.

Interaksi sosial-budaya antar warga di Amerta Residence cukup baik, meskipun tidak dapat dihindari adanya sedikit gesekan antar warga karena sikap ego warga yang mayoritas berlatar belakang usia muda dalam berkelurga. Namun, gesekan itu tergerus begitu saja sebab mereka saling menghormati satu sama lain dan tolong-menolong jika ada warga yang mengalami musibah atau kesusahan. Mereka saling bertukar pengalaman dan bekerjasama untuk membangun Amerta Residence yang bersih, guyup, rukun, dan aman.

Kegiatan yang ada di Amerta Residence sangat banyak dan terstruktur. Ada kegiatan bakti sosial berbagi rezeki pada fakir miskin dan anak yatim, kegiatan ibu-ibu PKK di setiap bulannya, pertemuan rutin bulanan bapak-bapak, kerja bakti satu bulan dua kali, ronda warga pada malam minggu, pembacaan yasin-tahlil setiap malam jum'at legi dan kegiatan hari-hari besar agama islam lainya seperti Isro' mi'roj, Maulud Nabi Muhammad SAW, tahun baru islam, pembagian ta'zil gratis, penyaluran zakat fitrah dan pelaksanaan penyembelihan qurban di Hari Raya Idul Adha. Akan tetapi, kegiatan itu semua menjadi tidak terlaksana saat pandemi Coronavirus Disease (Covid-19) yang melanda Indonesia.

Desa Saptorenggo pada bulan Maret 2020 dinyatakan sebagai zona merah waspada Covid-19 sehingga semua kegiatan yang mengumpulkan massa sementara ditiadakan. Selain itu, Desa Saptorenggo juga merupakan daerah yang rawan penyebaran Covid-19 karena dilalui oleh banyak orang yang menggunakan transportasi jalur udara maupun darat yang ingin berwisata ke Gunung BromoSemeru. Selain itu, banyaknya penduduk Desa Saptorenggo yang bekerja dari Kabupaten ke Kota Malang menjadikan kekhawatiran yang besar akan penyebaran Covid-19. Begitu juga dengan warga Amerta Residence yang mayoritas bekerja ke Kota Malang dan luar Kota Malang. Padahal, selama masa pandemi Covid-19 =seharusnya warga tidak perlu bepergian ke daerah yang ditemukan adanya penyebaran Covid-19 dan diharuskan untuk berdiam dan beraktivitas di rumah saja (Jabbar, 2020). Hal ini menjadi permasalahan besar dan berbahaya di masa pandemi Covid-19 jika tidak ada solusi yang tepat untuk diberikan kepada warga Amerta Residence. Perlu adanya koordinasi dan kolaborasi antara ketua RT 08 dan warga Amerta Residence untuk melakukan pencegahan penyebaran Covid-19 di lingkungan Amerta Residence.

Diskusi intens secara langsung maupun via WhatsApp yang dilakukan oleh tim pengabdian dengan ketua RT 08 dan warga Amerta Residence dalam pencegahan penyebaran Covid-19 di lingkungan Amerta Residence. Hasil diskusi tersebut menemukan kesepakatan bersama bahwa diperlukan adanya kegiatan sosialisasi melalui musyawarah warga dan pendampingan untuk melakukan penyemprotan disinfektan selama pandemi Covid-19. Dengan demikian, solusi yang ditawarkan pada kegiatan pengabdian kepada masyarakat ini di Amerta Residence RT 08, yaitu sosialisasi dan pendampingan pencegahan penyebaran Covid-19.

\section{METODE PELAKSANAAN}

Jenis kegiatan yang dilaksanakan adalah pengabdian kepada masyarakat. Kegiatan pengabdian kepada masyarakat dilaksanakan pada bulan Maret s.d Juni 2020. Tempat dilaksanakannya 
pengabdian adalah di Amerta Residence RT 08 / RW 05 Desa Saptorenggo, Kecamatan Pakis, Kabupaten Malang. Target atau sasaran pengabdian, yaitu pencegahan penyebaran Covid-19 di lingkungan Amerta Residence. Subjek pengabdian adalah seluruh warga perum Amerta Residence RT 08.

Prosedur pelaksanaan kegiatan pengabdian kepada masyarakat di Perum Amerta Residence RT 08 terdiri atas 4 tahapan sebagai berikut.

1. Sosialisasi melalui musyawarah warga Amerta Residence RT 08. Agenda dalam kegiatan ini, yaitu pendataan kesehatan warga Amerta Residence, penetapan protokol kesehatan Amerta Residence, edukasi menjaga kesehatan diri sendiri, keluarga dan lingkungan, serta penyusunan rencana kegiatan pencegahan penyebaran Covid-19 selama pandemi.

2. Pembentukan tim Tanggap Covid (PTC) Amerta Residence RT 08. Pembentukan tim PTC ini bertujuan untuk mempercepat pencegahan penyebaran Covid-19 di lingkungan Amerta Residence RT 08.

3. Pendampingan penyemprotan disinfektan secara berkala tim Perum Tanggap Covid (PTC). Pendampingan ini bertujuan untuk mengoptimalkan pencegahan penyebaran Covid-19 di lingkungan Amerta Residence

4. Evaluasi kegiatan pengabdian kepada masyarakat. Instrumen evaluasi yang digunakan, yaitu lembar pengamatan keterlaksanaan kegiatan dan didukung dengan foto dokumentasi kegiatan pengabdian kepada masyarakat.

\section{HASIL DAN PEMBAHASAN \\ Sosialisasi melalui musyawarah warga Amerta Residence RT 08}

Hasil sosialisasi melalui musyawarah warga Amerta Residence RT 08 pada tanggal 7 Maret 2020, yaitu sebagai berikut.

1. Pendataaan kesehatan warga Amerta Residence

Pendataan kesehatan warga dilakukan dengan kolaborasi bersama petugas Pukesmas Pakis Kabupaten Malang dalam Program Keluarga Sehat (KS) pada tanggal 20 Februari 2020. Hasil pendataan kesehatan diperoleh bahwa warga Amerta Residence sebanyak 40 Kepala Keluarga (KK) dengan jumlah warga 105 orang dengan rincian orang dewasa sebanyak 85 orang dan anak kecil sebanyak 20 orang semuanya dalam kondisi sehat, mayoritas kepala rumah tangga adalah perokok $(65 \%)$ sedangkan kepala rumah tangga lainya adalah non-perokok (35\%), dan seluruh warga tidak memiliki riwayat penyakit kronis. Dengan demikian, dari kegiatan pendataan kesehatan warga Amerta Residence inilah tim pengabdian memperoleh informasi yang valid bahwa sampai awal bulan Maret 2020 warga Amerta Residence tidak ada yang sakit dan tidak ada indikasi penyebaran Covid-19. Bukti stiker kegiatan pendataan kesehatan warga Amerta Residence dapat dilihat pada Gambar 1.

Pendataan kesehatan warga tempat pengabdian sangat penting untuk dilakukan karena melalui data kesehatan warga tersebut tim pengabdian dapat memperoleh informasi valid tentang masalah kesehatan warga tempat pengabdian. Selain itu, melalui data kesehatan tim pengabdian dapat memberikan pelayanan kepada warga Amerta Residence yang sedang mengalami sakit melalui konsultasi dan pemberian obat. Perlunya pendataan kesehatan pada kegiatan pengabdian kepada masyarakat ini sejalan dengan program Indonesia Sehat dengan pendekatan keluarga, 
yaitu meningkatkan derajat kesehatan dan status gizi masyarakat Indonesia (Kemenkes RI, 2017). Virdasari et al., (2018) menambahkan bahwa pendataan kesehatan harus dilakukan untuk mengetahui masalah kesehatan masyarakat sehingga dapat dilakukan pelayanan untuk meningkatkan kesehatan masyarakat.

Hasil pendataan kesehatan mitra menunjukkan bahwa warga Amerta Residence tidak ada yang sakit dan tidak memiliki riwayat penyakit kronis. Kondisi tubuh yang sehat akan terhindar dari segala macam penyakit. Sehat membuat semua warga Amerta Residence dapat beraktivitas dengan baik tanpa hambatan sedikitpun seperti berkerja dan bersosialisasi. Pernyataan di atas sesuai dengan penjelasan Kemenkes RI (2016) bahwa kesehatan adalah manivestasi dalam mendukung pembangunan ekonomi dan juga penanggulangan akan kemiskinan di masyarakat. Agustina et al. (2019) menambahkan bahwa kesehatan merupakan hal penting untuk pembangunan, pencegahan penyakit, dan pemberdayaan masyarakat.

Kondisi sehat dari seluruh warga Amerta Residence memberikan stimulasi besar untuk pelaksanaan kegiatan pengabdian kepada masyarakat untuk melakukan pencegahan penyebaran Covid-19. Kondisi sehat menjadi benteng untuk melawan berbagai sumber penyakit. Kondisi sehat membuat tubuh mampu melaksakan seluruh fungsi fisiologi sistem organ tubuh untuk bekerja secara optimal. Pernyataan di atas sesuai dengan hasil penelitian Nurdiawati \& Atiatunnisa (2018) bahwa tubuh yang sehat dipengaruhi oleh kerja fisiologis tubuh yang baik. Respon fisiologi yang baik akan memberikan kondisi tubuh yang sehat untuk melakukan aktivitas seperti bekerja (Wulandari \& Ernawati, 2018). Carl, Sudeck, \& Pfeifer (2020) menjelaskan bahwa tubuh yang sehat mampu mendukung aktivitas fisik secara optimal dan sebaliknya.

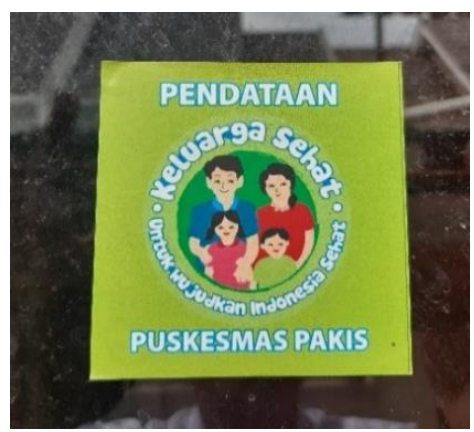

Gambar 1. Stiker Pendataan Keluarga Sehat

2. Penetapan Protokol Kesehatan Amerta Residence

Bermula dari informasi mengenai menyebarnya Covid-19 di Malang Raya pada pertengahan bulan Maret 2020, yaitu diketahui jumlah daftar Orang Dalam Pengawasan (ODP) sebanyak 24 orang, Pasien Dalam Pengawasan (PDP) sebanyak 8 orang, dan Pasien Positif (PP) sebanyak 2 orang (Azmi, 2020). Selanjutnya, jumlah pasien positif diperkirakan akan terus bertambah (Arifin, 2020b). Berdasarkan informasi di atas, tim pengabdi dan mitra yang diwakili oleh ketua RT 08 Bapak Agus Priyono dan warga melakukan koordinasi dan diskusi untuk menerapkan protokol kesehatan di Amerta Residence untuk mencegah penyebaran Covid-19. Hasil koordinasi dan diskusi tentang peraturan Amerta Residence selama pandemi Covid-19 dapat dilihat pada Tabel 1.

Tabel 1. Protokol Kesehatan Amerta Residence RT 08 Selama Pandemi Covid-19

\begin{tabular}{|l|l|}
\hline \multicolumn{1}{|c|}{ Aspek } & \multicolumn{1}{c|}{ Protokol Kesehatan } \\
\hline Bertamu & $\begin{array}{l}\text { Tamu harus menunjukkan identitas } \\
\text { kepada Satpam dan sementara tidak } \\
\text { diperbolehkan menerima banyak } \\
\text { tamu }\end{array}$ \\
\hline $\begin{array}{l}\text { Interaksi } \\
\text { warga }\end{array}$ & $\begin{array}{l}\text { Jaga jarak saat berkomunikasi, } \\
\text { gunakan masker, sering mencuci } \\
\text { tangan, dan saling menolong }\end{array}$ \\
\hline Lingkungan & $\begin{array}{l}\text { Harus menjaga kebersihan } \\
\text { lingkungan seperti memasukkan } \\
\text { sampah kedalam kantong sampah }\end{array}$ \\
\hline
\end{tabular}




\begin{tabular}{|l|l|}
\hline \multicolumn{1}{|c|}{ Aspek } & \multicolumn{1}{|c|}{ Protokol Kesehatan } \\
\hline & $\begin{array}{l}\text { sebelum dibuang di tempat sampah } \\
\text { untuk menghindari kedatangan lalat } \\
\text { dan kuman-kuman lain penyebab } \\
\text { penyakit }\end{array}$ \\
\hline $\begin{array}{l}\text { Alat } \\
\text { komunikasi }\end{array}$ & $\begin{array}{l}\text { Memaksimalkan WhatsApp (WA) } \\
\text { sebagai alat komunikasi warga } \\
\text { Amerta Residence }\end{array}$ \\
\hline Portal perum & $\begin{array}{l}\text { Portal perum dibuka pukul 05.00 } \\
\text { WIB dan ditutup pukul 22.00 WIB } \\
\text { serta tamu wajib lapor }\end{array}$ \\
\hline $\begin{array}{l}\text { Pekerja luar } \\
\text { kota }\end{array}$ & $\begin{array}{l}\text { Berusaha untuk mengurus surat } \\
\text { domisili sebagai data identitas diri } \\
\text { jika sewaktu-waktu diperlukan dan } \\
\text { selalu waspada terhadap Covid-19 } \\
\text { serta diupayakan mengikuti } \\
\text { peraturan pemerintah }\end{array}$ \\
\hline $\begin{array}{l}\text { Lawan } \\
\text { Covid-19 }\end{array}$ & $\begin{array}{l}\text { Pembentukan tim PTC Amerta } \\
\text { Residence dengan tugas melakukan } \\
\text { penyemprotan disinfektan secara } \\
\text { berkala di lingkungan Amerta } \\
\text { Residence dan penyemprotan } \\
\text { disinfektan dilakukan satu minggu } \\
\text { 2 kali }\end{array}$ \\
\hline Pertemuan \\
rutin warga & $\begin{array}{l}\text { Sementara ditiadakan sampai } \\
\text { pandemi Covid-19 berakhir }\end{array}$ \\
\hline
\end{tabular}

Peraturan interaksi sosial warga di Amerta Residence RT 08 selama pandemi Covid-19 sangat penting untuk disusun, disosialisasikan dan diterapkan. Hal ini sangat perlu dilakukan untuk mencegah penyebaran Covid-19 di lingkungan Amerta Residence. Pernyataan di atas sejalan dengan pernyataan Kemenkes RI (2020) bahwa pencegahan Covid-19 di tingkat RT/RW/Desa selama pandemi dapat dilakukan dengan menerapkan peraturan yaitu menjaga jarak fisik (physical distancing) seperti tidak boleh berdekatan dengan orang lain atau harus mengatur jarak minimal 1 s.d 2 meter, hindari berpergian dengan transportasi umum, tinggal di rumah saja, bekerja dan belajar dari rumah, tidak boleh berkerumun, tidak boleh berpergian ke luar kota, harus membiasakan cuci tangan dan menggunakan masker saat sakit atau keluar rumah.

Protokol kesehatan yang diterapkan oleh mitra yaitu Amerta Residence RT 08 sesuai dengan peraturan keluar dan masuk rumah selama pandemi Covid-19 yang ditetapkan oleh pemerintah Malang Raya seperti jaga jarak aman dengan orang lain, gunakan masker, sering mencuci tangan dan area kulit yang terpapar oleh udara luar, buka pakaian dan masukkan langsung ke tempat cucian, serta belajar, bekerja, dan beribadah untuk dapat dilaksanakan di rumah masing-masing (Arifin, 2020a). Kemenkes RI (2020a) menambahkan bahwa penyebaran Covid-19 di masyarakat dapat dilakukan dengan menerapkan beberapa aturan seperti melakukan kebersihan tangan, memakai masker saat keluar rumah, menerapkan etika batuk dan bersin, jangan menyentuh mata, hidung, dan mulut serta jaga jarak dari orang lain terutama yang sakit saluran pernapasan. Selain itu, peraturan di Amerta Residence juga sejalan dengan fatwa Majelis Ulama Indonesia (MUI) bahwa daerah zona merah sementara dilarang melaksanakan ibadah dengan memuat massa seperti berjamaah sholat lima waktu dan berjamaah salat jumat di masjid dan dilarang mengadakan majelis taklim dengan tujuan agar masyarakat dapat menjaga kesehatan dan terjauh dari sumber infeksi Covid-19 (Muchid, 2020).

3. Edukasi menjaga kesehatan diri sendiri, keluarga, dan lingkungan

Hasil kegiatan edukasi kesehatan kepada warga Amerta Residence yang berupa rangkuman isi edukasi kesehatan disajikan pada Tabel 2.

Tabel 2. Rangkuman Isi Edukasi Kesehatan Warga Perum Amerta Residence

\begin{tabular}{|l|ll|}
\hline \multicolumn{1}{|c|}{ Narasumber } & Rangkuman Isi Edukasi \\
\hline Ketua RT & $\begin{array}{l}\text { Warga harus waspada } \\
\text { dengan Covid-19 dan tidak }\end{array}$ \\
\hline
\end{tabular}




\begin{tabular}{|c|c|}
\hline Narasumber & Rangkuman Isi Edukasi \\
\hline & $\begin{array}{l}\text { boleh menganggap remeh } \\
\text { Covid-19 } \\
\text { Warga harus saling } \\
\text { berkomunikasi melalui } \\
\text { WhatsApp Group agar } \\
\text { semua kondisi warga dapat } \\
\text { dipantau dan jika ada hal- } \\
\text { hal yang tidak diinginkan } \\
\text { terjadi bisasegera } \\
\text { ditanggulangi } \\
\text { Warga harus patuh dengan } \\
\text { peraturan pemerintah pusat } \\
\text { dan peraturan Desa } \\
\text { Saptorenggo serta peraturan } \\
\text { Amerta Residence RT 08 } \\
\text { Warga harus selalu menjaga } \\
\text { lingkungan agar tetap bersih } \\
\text { dan terhindar dari ancaman } \\
\text { bibit penyakit } \\
\text { Warga tidak boleh } \\
\text { mendiskriminasikan warga } \\
\text { lain yang sedang mengalami } \\
\text { flu dan batuk agar situasi } \\
\text { warga Amerta Resindence } \\
\text { tetap tenang } \\
\text { Warga tidak boleh panik } \\
\text { dan tetap tenang dalam } \\
\text { menghadapi pandemi } \\
\text { Covid-19 karena Amerta } \\
\text { Residence sudah } \\
\text { menetapkan peraturan } \\
\text { selama pandemi Covid-19 } \\
\text { dan membentuk tim Perum } \\
\text { Tanggap Covid (PTC) }\end{array}$ \\
\hline Sie Keagamaan & $\begin{array}{l}\text { 1. Warga Amerta Residence } \\
\text { harus selalu mendekatkan } \\
\text { diri pada Allah SWT dengan } \\
\text { cara menjalankan ibadah } \\
\text { wajib dan sunah agar Allah } \\
\text { SWT selalu memberikan } \\
\text { kesehatan dan perlindungan } \\
\text { kepada diri kita, keluarga } \\
\text { kita, dan lingkungan kita } \\
\text { 2. Warga disarankan untuk } \\
\text { mengamalkan zikir istigfar } \\
\text { dan selawat nabi agar selalu } \\
\text { mendapatkan pertolongan } \\
\text { dari Allah SWT } \\
\text { Warga harus tetap } \\
\text { menjalankan sunah tata cara } \\
\text { bersuci dan makan dengan }\end{array}$ \\
\hline
\end{tabular}

\begin{tabular}{|c|c|}
\hline Narasumber & Rangkuman Isi Edukasi \\
\hline & $\begin{array}{l}\text { baik agar tubuh kita terhidar } \\
\text { dari berbagai macam } \\
\text { sumber penyakit } \\
\text { 4. Warga harus selalu berbaik } \\
\text { sangka pada para tetangga } \\
\text { agar menciptakan situasi } \\
\text { yang aman dan tentram } \\
\text { selama pandemi Covid-19 } \\
\text { 5. Sementara kegiatan rutinan } \\
\text { yasin-tahlil ditiadakan } \\
\text { sampai pandemi Covid-19 } \\
\text { berakhir seperti himbauan } \\
\text { pemerintah dan pengurus } \\
\text { besar Nahdatul Ulama Jawa } \\
\text { Timur }\end{array}$ \\
\hline Tim Pengabdian & $\begin{array}{l}\text { 1. Covid-19 adalah spesies } \\
\text { virus yang berbahaya dan } \\
\text { tidak boleh kita anggap } \\
\text { remeh } \\
\text { 2. Virus yang masuk kedalam } \\
\text { tubuh kita akan dilawan } \\
\text { oleh antibodi tubuh. Hanya } \\
\text { antibodi tubuh kitalah yang } \\
\text { bisa mematikan virus. } \\
\text { Antibodi tubuh dapat } \\
\text { diproduksi dengan baik jika } \\
\text { kita mengonsumsi makanan } \\
\text { bergizi yang mengandung } \\
\text { nutrisi dan vitamin } \\
\text { pendukung pembentukan } \\
\text { antibodi tubuh. Oleh karena } \\
\text { itu, mulai sekarang kita } \\
\text { perlu membiasakan diri } \\
\text { untuk mengonsumsi makan } \\
\text { bergizi agar antibodi tubuh } \\
\text { kita terus diproduksi. } \\
\text { Kerja antibodi dipengaruhi } \\
\text { oleh kondisi tubuh kita. } \\
\text { Kurang tidur menyebabkan } \\
\text { antibodi tubuh bekerja } \\
\text { kurang maksimal sehingga } \\
\text { disarankan untuk istirahat } \\
\text { cukup dan tidak perlu } \\
\text { begadang tanpa tujuan yang } \\
\text { penting. Stres adalah faktor } \\
\text { yang penyebab lemahnya } \\
\text { kerja antibodi tubuh kita. } \\
\text { Kita harus berusaha untuk } \\
\text { tidak stres. Jika ada } \\
\text { permasalahan kita tetap } \\
\text { rileks dan mencari solusi }\end{array}$ \\
\hline
\end{tabular}




\begin{tabular}{|l|l|}
\hline Narasumber & Rangkuman Isi Edukasi \\
\hline & $\begin{array}{l}\text { dengan tenang serta tidak } \\
\text { boleh panik. }\end{array}$ \\
5. & $\begin{array}{l}\text { Selain virus, } \\
\text { mikroorganisme parasit lain } \\
\text { seperti bakteri, jamur, dan } \\
\text { protozoa harus kita hambat } \\
\text { pertumbuhannya dengan } \\
\text { menjaga kebersihan diri, } \\
\text { keluarga dan lingkungan. } \\
\text { Seperti kita harus } \\
\text { membiasakan sering cuci } \\
\text { tangan atau menggunakan } \\
\text { handsanitizer, mandi } \\
\text { minimal } 2 \text { kali sehari, } \\
\text { menggunakan masker saat } \\
\text { keluar rumah, membuang } \\
\text { sampah dengan cara yang } \\
\text { benar dan jaga jarak saat } \\
\text { berkomunikasi dengan } \\
\text { orang lain. } \\
\text { Penyemprotan disinfektan } \\
\text { sangat penting di } \\
\text { lingkungan Amerta } \\
\text { Residence selama pandemi } \\
\text { Covid-19. Penyemprotan } \\
\text { dilakukan pada pagar rumah } \\
\text { dan jalan perum sehingga } \\
\text { lingkungan Amerta } \\
\text { Residence terhindar dari } \\
\text { Covid-19 dan parasit } \\
\text { lainnya } \\
\text { Warga dihimbau untuk } \\
\text { menjaga kebersihan rumah } \\
\text { masing-masing dengan } \\
\text { secara rutin membersihakan } \\
\text { peralatan rumah tangga } \\
\text { dengan disinfektan atau } \\
\text { antiseptik. }\end{array}$ \\
\hline
\end{tabular}

Edukasi menjaga kesehatan diri, keluarga dan lingkungan menjadi hal penting dalam memahamkan warga Amerta Residence agar bisa mencegah penyebaran Covid-19. Kegiatan edukasi ini memberikan penjelasan tentang interaksi sosial, keyakinan akan perlindungan Tuhan dari segala penyakit, pola makan sehat dan penyemprotan disinfektan selama pandemi Covid-19. Pentingnya aturan interaksi sosial, berdoa, pola makan, dan penyemprotan disinfektan perlu untuk disampaikan kepada mitra agar mereka sadar bahwa hal-hal itulah yang perlu dilakukan agar terhindar dari infeksi Covid-19. Pernyataan di atas sesuai dengan hasil penelitian Fakhri (2020) bahwa seluruh masyarakat harus ikut berperan dalam menekan jumlah orang positif Covid-19 dan melakukan kegiatan yang mencegah infeksi Covid-19 seperti pola makan sehat, membersihkan tubuh dan lingkungan, berdoa dan physical distancing. Tian et al. (2020) menambahkan bahwa jaga jarak fisik, isolasi pada pasien Covid-19 dan karantina sangat berhasil untuk mencegah penularan Covid-19 di masyarakat.

Edukasi pola makan yang baik yaitu dengan mengonsumsi makan bergizi juga akan mampu meningkatkan imunitas tubuh masyarakat sehingga mereka dapat terhindar dari infeksi Covid-19. Pertanyataan di atas sesuai dengan pernyataan Muhammad (2020) bahwa pola makan yang baik seperti mengonsumsi rimpang-rimpangan dapat meningkatkan daya tahan tubuh atau imun. Febry (2020) menambahkan bahwa suplai zat gizi dari konsumsi makanan beragam melalui pola makan yang baik akan meningkatkan imun tubuh seperti konsumsi buah-buahan, kurangi konsumsi gorengan dan makanan berlemak tinggi serta konsumi sayur-sayuran dan sumber protein hewani yang cukup. Pola makan dengan mengonsumsi makanan gizi seimbang dapat mengaktifkan sistem imun tubuh seperti konsumsi nasi, umbi-umbian, buah, sayur, kacang-kacangan, daging sapi, daging ayam dan ikan (Puspitasari, 2020).

4. Penyusunan rencana kegiatan selama pandemi Covid-19

Rencana kegiatan warga perum Amerta Residence selama pandemi Covid-19 dapat dilihat pada Tabel 3 berikut ini. 
Tabel 3. Rencana Kegiatan Warga Amerta Residence Selama Pandemi Covid-19

\begin{tabular}{|c|c|}
\hline Bulan & Kegiatan \\
\hline April & $\begin{array}{ll}\text { 1. } & \begin{array}{l}\text { Kerja bakti taman belakang } \\
\text { dengan tetap menjaga jarak }\end{array} \\
\text { 2. } & \begin{array}{l}\text { Penyemprotan disinfektan } \\
\text { setiap minggu } 2 \text { kali yaitu hari } \\
\text { rabu sore dan hari minggu } \\
\text { sore }\end{array} \\
\text { 3. } & \text { Ronda malam dengan tetap } \\
\text { menjaga jarak (mulai: } 22.00 \\
\text { s.d 02.30) }\end{array}$ \\
\hline Mei-Juni & 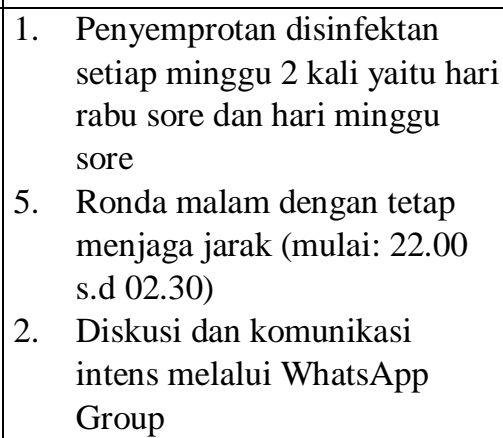 \\
\hline
\end{tabular}

Penetapan rencana kegiatan mitra pengabdian selama pandemi Covid-19 adalah bersifat sangat penting. Melalui rancangan kegiatan inilah warga Amerta Residence akan menjalankan aktivitas sosialnya selama pandemi Covid-19. Rencana kegiatan yang tepat selama pandemi Covid-19 akan mendukung pencegahan penyebaran Covid19. Kegiatan perencanaan di atas sesuai dengan pernyataan Kemenkes RI (2020b) bahwa usaha yang perlu dilakukan untuk pencegahan Covid-19 berbasis pemberdayaan masyarakat melalui tahapan sebagai berikut. (1) Perlu melaksanakan pendataan kesehatan tingkat RT. (2) Diperlukan deteksi pada faktor penyebab penularan Covid-19 dan potensi wilayah. (3) Perlu dilakukan musyawarah dengan masyarakat untuk melakukan edukasi kepada masyarakat. (4) Perlu menyusun rencana kegiatan selama masa pandemi Covid-19. (5) Perlu pelaksanaan kegiatan sesuai rencana yang telah ditetapkan. (6) Perlu evaluasi pada pelaksanaan kegiatan untuk keberlangsungan kegiatan yang telah dilaksanakan.

\section{Pembentukan tim Perum Tanggap Covid (PTC) Amerta Residence RT 08}

Penetapan tim PTC Amerta Residence dirasa sangat penting untuk mencegah persebaran Covid19 di Amerta Residence. Penetapan tim PTC ini melalu proses komunikasi intens dengan ketua RT 08 dan perwakilan warga melalui Chatting via WhatsApp dan tiga kali tatap muka. Ketua RT 08 dan warga setuju untuk dibentuk tim PTC Amerta Residence agar Amerta Residence terhindar dari ancaman Covid-19. Susunan tim PTC Amerta Residence sebagai berikut.

1) Penanggungjawab: Ketua RT 08

2) Ketua tim: Muh. Zulfikar

3) Bendara: Dwi Purnomo

4) Sekretaris: Timor Prayogo

5) Ko. sie perlengkapan: Beni Prasetyo

6) Ko. sie pelaksana penyemprotan: Marco Atdika

Tugas utama tim PTC Amerta Residence adalah melaksanakan penyemprotan disinfektan secara berkala di lingkungan perum Amerta Residence. Tugas lainnya adalah menerima laporan atau informasi dai warga terkait persebaran Covid-19 di Malang Raya dan pencegahan penyebaran Covid-19 di perum Amerta Residence. Pembentukan tim PTC mitra pada program pengabdian kepada masyarakat ini sejalan dengan isi Surat Edaran Kemendes PDTT Republik Indonesia Nomor 8 Tahun 2020 mengenai pembentukan relawan lawan Covid-19 (Kemendes PDTT, 2020). Berbeda dengan relawan lawan Covid-19 tingkat Desa, tim PTC mitra pengabdian dibentuk oleh tim pengabdian dan ketua RT 08 perum Amerta Residence untuk menjadi relawan lawan Covid-19 di lingkungan perum Amerta Residence RT 08 sehingga dapat mencegah penyebaran Covid-19. 


\section{Pendampingan penyemprotan disinfektan secara berkala tim Perum Tanggap Covid (PTC)}

Pendapingan penyemprotan disinfektan pada mitra pengabdian sangat perlu dilakukan oleh tim pengabdian dengan tujuan untuk memberikan pengetahuan kepada mitra khususnya tim PTC dan warga Amerta Residen dalam melakukan penyemprotan disinfektan di lingkungan perum Ameta Residence. Diawali oleh tim pengabdian menjelaskan bahan-bahan kimia yang digunakan untuk pembuatan disinfektan. Bahan-bahan kimia yang digunakan untuk membuat disinfektan diperoleh dari Laboratorium Biologi IKIP Budi Utomo, yaitu senyawa hidrogen peroksida $\left(\mathrm{H}_{2} \mathrm{O}_{2}\right)$, asam klorida ( $\mathrm{HCl})$, baiclin (larutan pemutih), dan lisol. Bahan-bahan kimia disinfektan dapat dilihat pada Gambar 2.

Selanjutnya tim pengabdian melakukan demostrasi pencampuran bahan-bahan kimia dengan air bersih. Perbandingan 2 sendok bahan kimia: 1 liter air bersih. Namun dalam praktiknya, tim pengabdian menggunakan perbandingan 20 sendok bahan kimia: 10 liter air bersih dikarenakan alat semprot yang dimiliki oleh Amerta Residence bervolume 10 liter. Ketika melakukan pencampuran bahan disinfektan, tim pengabdi dan mitra harus menggukan sarung tangan agar dan masker. Sarung tangan berguna untuk melindungi kulit tangan dari bahan-bahan kimia agar tidak iritasi. Masker berguna untuk menghindari bau menyengat dari bahan kimia dan pelindung diri dari Covid-19 dan parasite lain yang bisa menular melalui udara. Proses pembuatan disinfektan dapat dilihat pada Gambar 3.

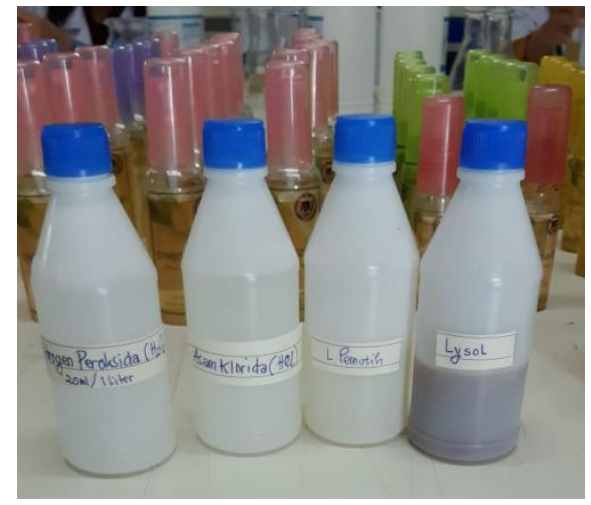

Gambar 2. Bahan-bahan Kimia Disinfektan

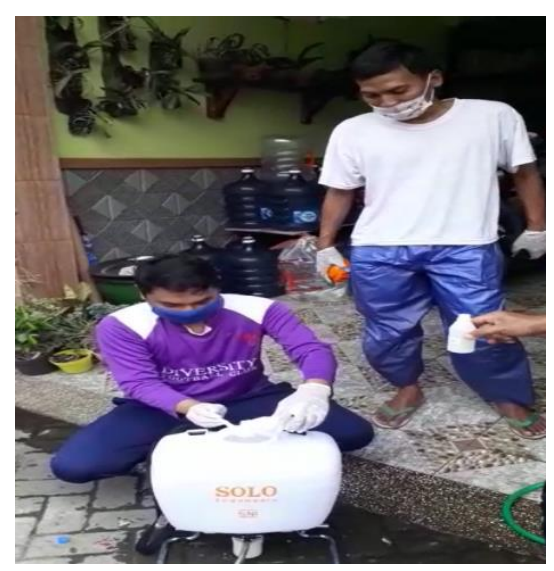

Gambar 3. Proses Pembuatan Disinfektan Dengan Perbandingan 20 sendok: 10 Liter Air Bersih

Proses penyemprotan disinfektan di lingkungan Amerta Residence dilaksanakan oleh tim PTC Amerta Residence dengan didampingi oleh tim pengabdian. Pendampingan ini bertujuan untuk memberikan pengetahuan tentang penyemprotan disinfektan yang tepat dan efektif. Penyemprotan disinfektan dilakukan pada pagar rumah warga dan jalan di Amerta Residence. Tim pengabdian dan mitra tidak melalukan penyemprotan di dalam rumah warga dikarenakan disinfektan bersifat berbahaya jika terkena kulit warga dan berbahaya bagi saluran pernapasan jika terhirup oleh warga. Petugas penyemprotan harus menggunakan Alat Pelindung Diri (APD) seperti helm, jas hujan, kaca mata, sarung tangan, masker dan sepatu agar 
terhidar dari infeksi Covid-19 dan parasite lainnya. Penyeprotan disinfektan di lingkungan Amerta Residence dapat dilihat pada Gambar 4. Kebersamaan tim pengabdian dan mitra tim PTC Amerta Residence dalam penyemprotan disinfektan dapat dilihat pada Gambar 5.

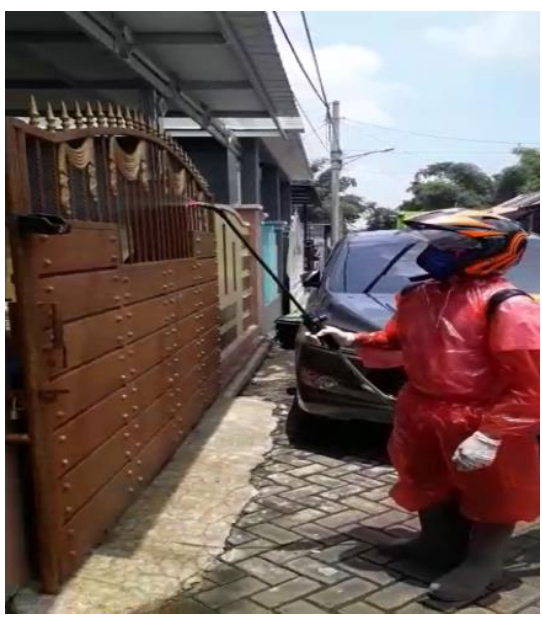

Gambar 4. Penyemprotan Disinfektan di Lingkungan Perum Amerta Residence

Bahan-bahan kimia disinfektan yang digunakan tim pengabdian dan mitra adalah bahan-bahan kimia yang direkomendasikan oleh Pemkot Malang (2020) seperti larutan pemutih, larutan klorin, lysol, pembersih lantai, diamin, dan peroksida. Disinfektan yang telah dibuat ampuh untuk membunuh virus dan parasit lainnya. Pernyataan di atas sesuai hasil penelitian Rutala \& Weber (2013) dan Young et al. (2017) bahwa penggunaan desinfektan efektif untuk membuhuh petogen penyebab penyakit. Gargi et al. (2015) dan Rutala \& Weber (2013b) menjelaskan bahwa desinfektan dapat membunuh patogen dengan cara merusak struktur dinding sel dan membran serta mengganggu metabolisme patogen.

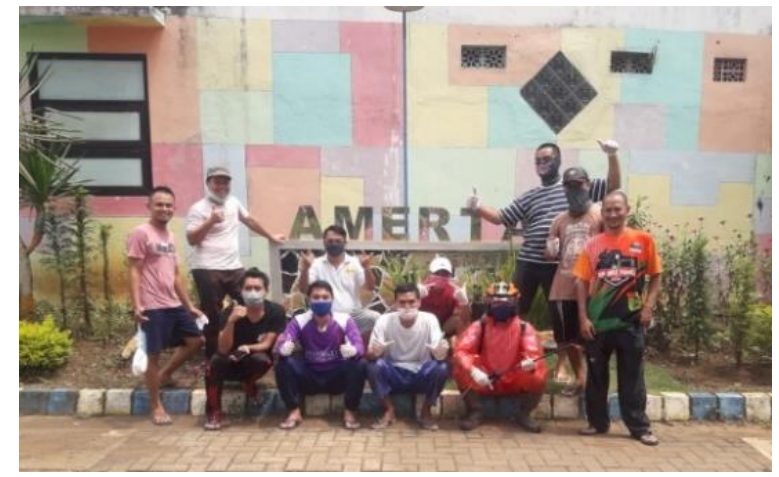

Gambar 5. Kebersamaan Tim Pengabdian dan Mitra Tim PTC Amerta Residence Dalam Penyemprotan Disinfektan

\section{Evaluasi kegiatan pengabdian kepada masyarakat di Perum Tanggap Covid (PTC) Amerta Residence}

Evaluasi kegiatan pengabdian kepada masyarakat di PTC Amerta Residence dilaksanakan oleh tim pengabdian dan warga tempat pengabdian yang diwakili oleh ketua RT 08 serta beberapa warga Amerta Residence. Hasil evaluasi kegiatan pengabdian kepada masyarakat mulai bulan Maret s.d Juni 2020 menunjukkan sebagai berikut. (1) Di bulan Maret s.d Juni 2020, warga Amerta Residence dalam kondisi sehat dan tidak ada yang sakit ataupun terhindar dari infeksi Covid-19. (2) Semua warga perum Amerta Residence mematuhi dan menjalankan peraturan yang telah ditetapkan di lingkunan Amerta Residence. (3) Perum Amerta Residence terlihat rapi dan bersih karena warga telah menerapkan pengetahuan pentingnya kesehatan diri sendiri, keluarga dan lingkungan. (4) Selama pencegahan penyebaran Covid-19, warga tempat pengabdian tidak mengalami konflik sosial dan seluruh warga Amerta Residence sangat kompak. (5) Tim PTC Amerta Residence dapat melaksanakan tugasnya dengan sangat baik.

(6) Seluruh warga Amerta Residence dapat melaksanakan rencana kegiatan selama pandemi Covid-19. (7) Warga perum Amerta 
Residence sangat antusias dalam pencegahan penyebaran Covid-19 di lingkungan Amerta Residence. (8) Bahan kimia disinfektan sangat ampuh dalam membasmi virus dan mikroba parasit lainnya, namun perlu dilakukan penggantian bahan kimia yang digunakan dalam pembuatan disinfektan dengan bahan disinfektan yang tepat karena residu bahan kimia disinfektan yang digunakan oleh tim pengabdian masih meninggalkan bercakbercak pada pagar atau mobil yang telah disemprot. Kegiatan evaluasi dalam pengabdian kepada masyarakat perlu dilakukan untuk mengetahui keberhasilan dari pelaksanaan pengabdian dan juga sebagai dasar untuk menentukan keberlanjutan dari kegiatan pengabdian yang telah dilaksanakan oleh tim pengabdian dan mitrak. Keberlanjutan kegiatan sangat penting bagi warga tempat pengabdian karena warga akan terus menerus merasakan manfaat dari kegiatan pengabdian kepada masyarakat.

\section{KESIMPULAN}

Tim pengabdian telah berhasil melaksanakan sosialisasi dan pendampingan pencegahan penyebaran Covid-19 di Perum Tanggap Covid (PTC) Amerta Residence RT 08 Desa Saptorenggo Kecamatan Pakis Kabupaten Malang selama bulan Maret s.d Juni 2020. Warga Amerta Residence dapat melaksanakan dengan baik semua tahapan pengabdian. Mitra mampu menyusun jadwal pemetaan kesehatan warga, menetapkan peraturan perum selama pandemic Covid-19, menyusun rencana kegiatan warga selama pandemi Covid-19, membentuk tim PTC untuk pencegahan penyebaran Covid-19, dan melaksanakan penyemprotan disinfektan secara berkala di lingkungan Amerta Residence. Perum Tanggap Covid Amerta Residence RT 08 siap lawan Covid-19.

\section{UCAPAN TERIMA KASIH}

Ucapan terimakasih ditujukan kepada Unit Penelitian dan Pengabdian kepada Masyarakat (P2M) IKIP Budi Utomo dan mitra pengabdian karena telah memberikan dukungan penuh untuk terlaksananya kegiatan pengabdian kepada masyarakat.

\section{DAFTAR PUSTAKA}

Agustina, S. C., Trisnantoro, L., \& Handono, D. (2019). Implementasi Program Indonesia Sehat dengan Pendekatan Keluarga (PIS PK) Menggunakan Tenaga Kontrak di Kabupaten Kulon Progo Tahun 2018. Jurnal Kebijakan Kesehatan Indonesia : JKKI, 8(3), 104112. https://doi.org/10.22146/JKKI.45705

Arifin, Z. (2020a). Ini Aturan Keluar Masuk Rumah Selama Pandemi Corona Covid19. Liputan 6. Retrieved from https://www.liputan6.com/otomotif/read /4214251/ini-aturan-keluar-masukrumah-selama-pandemi-corona-Covid19

Arifin, Z. (2020b). Update Corona Covid-19 di Malang Raya Jum 'at 27 Maret 2020. Liputan 6. Retrieved from https://www.liputan6.com/regional/read/ 4213114/update-corona-Covid-19-dimalang-raya-jumat-27-maret-2020

Azmi, F. (2020). Surabaya dan Malang Masuk Zona Merah Sebaran Virus Corona. Detiknews. Retrieved from https://news.detik.com/berita-jawatimur/d-4946844/surabaya-dan-malangmasuk-zona-merah-sebaran-viruscorona

Carl, J., Sudeck, G., \& Pfeifer, K. (2020). Competencies for a Healthy Physically Active Lifestyle-Reflections on the Model of Physical Activity-Related 
Health Competence. Journal of Physical Activity and Health, 17(7), 1-10. https://doi.org/10.1123/jpah.2019-0442

Fakhri, N. (2020). Respon Masyarakat Terhadap Covid-19. Pusat Kajian Psikologi Sosial UNM, April, 1-3. Retrieved from https://www.researchgate.net/publicatio n/340599055_Respon_Masyarakat_terh adap_Covid19

Febry, A. B. (2020, April). Gizi Untuk Melawan Covid-19. Direktorat Jenderal Pelayanan Kesehatan, 1-4. Retrieved from

http://www.yankes.kemkes.go.id/readgizi-untuk-melawan-covid19-8641.html

Gargi, R., Harshad, V., Mukesh, P., \& Jadhav, R. (2015). Efficacy of Some Antiseptics and Disinfectants. IJPPR (Internasional Journal of Pharmacy \& Pharmaceutical Research), 4(4), 183-197. https://doi.org/10.13140/RG.2.2.13897. 44640

Jabbar, A. A. (2020). Hadits Anjuran Rasulullah untuk Tetap di Rumah Selama Wabah Penyakit. Madaninews.id. Retrieved from https://www.madaninews.id/11213/hadit s-anjuran-rasulullah-untuk-tetap-dirumah-selama-wabah-penyakit.html

Kemendes PDTT. (2020). Surat Edaran Nomor 8 Tahun 2020 Tentang Desa Tanggap Covid-19 Dan Penegasan Padat Karya Tunai Desa. In Menteri Desa, Pembangunan Daerah Tertinggal, Dan Transmigrasi Republik Indonesia (8 Tahun 2020; pp. 1-5). Retrieved from http://www.bpkp.go.id/public/upload/un it/kaltim/files/SE_Mendes_8_2020_Des a_Tanggap_Covid-19.pdf

Kemenkes RI. (2016). Buku Pedoman Umum
Program Indonesia Sehat Dengan Pendekatan Keluarga. Kementerian Kesehatan RI. Retrieved from https://www.kemkes.go.id/folder/view/0 1/structure-web-content-download.html

Kemenkes RI. (2017). Program Indonesia Sehat dengan Pendekatan Keluarga. Kemenkes RI, 1(1), 1-5. Retrieved from http://www.depkes.go.id/article/view/17 070700004/program-indonesia-sehatdengan-pendekatan-keluarga.html

Kemenkes RI. (2020a). Pedoman Pencegahan dan Pengendalian Coronavirus disease (Covid-19). In Pedoman kesiapan menghadapi Covid-19. Kementerian Kesehatan RI. Retrieved from https://www.kemkes.go.id/folder/view/0 1/structure-download-lainnya.html

Kemenkes RI. (2020b). Pedoman Permberdayaan Masyarakat dalam Pencegahan Covid-19 di RT/RW/Desa. Kementerian Kesehatan RI. Retrieved from

https://www.kemkes.go.id/folder/view/0 1/structure-download-lainnya.html

Muchid, M. (2020). Fatwa MUI: Daerah Darurat Corona Dilarang Salat Id dan Jumat. Malang Post (Portal Berita Malang Raya). Retrieved from https://www.malangpost.com/berita/detail/fatwa-muidaerah-darurat-corona-dilarang-salatjumat

Muhammad, D. R. A. (2020, March). Pola Makan Sehat dan Bergizi untuk Meningkatkan Imunitas saat Terserang Covid-19. UNS-Opinion, 1-9. Retrieved from https://uns.ac.id/id/unsopinion/pola-makan-sehat-dan-bergiziuntuk-meningkatkan-imunitas-saatterserang-Covid-19.html 
Nurdiawati, E., \& Atiatunnisa, N. (2018). Hubungan Stres Kerja Fisiologis, Stres Kerja Psikologis dan Stres Kerja Perilaku Dengan Kinerja Karyawan. Faletehan Health Journal, 5(3), 117122. https://doi.org/10.33746/fhj.v5i3.24

Pemkot Malang. (2020). Komposisi Pembuatan Larutan Desinfektan. Retrieved from http://malangkota.go.id

Puspitasari, I. (2020, March). Pola Hidup Sehat Lawan Covid-9. Fakultas Farmasi Universitas Gadjah Mada, 2-8. Retrieved from https://farmasi.ugm.ac.id/id/pola-hidupsehat-lawan-Covid-19

Rutala, W. A., \& Weber, D. J. (2013a). Disinfectants used for environmental disinfection and new room decontamination technology. American Journal of Infection Control, $41(5$ SUPPL.), S36-S41. https://doi.org/10.1016/j.ajic.2012.11.00 6

Rutala, W. A., \& Weber, D. J. (2013b). Disinfection and Sterilization: An overview. American Journal of Infection Control, $41(5 \quad$ SUPPL.), S2-S5. https://doi.org/10.1016/j.ajic.2012.11.00 5

Saptorenggo, T. D. (2017). Profil Desa Saptorenggo: Gambaran Umum. Website Resmi Desa Saptorenggo Kecamatan Pakis Kabupaten Malang. Retrieved from http://desasaptorenggo.malangkab.go.id/

Tian, S., Hu, N., Lou, J., Chen, K., Kang, X., Xiang, Z., Chen, H., Wang, D., Liu, N., Liu, D., Chen, G., Zhang, Y., Li, D., Li, J., Lian, H., Niu, S., Zhang, L., \& Zhang, J. (2020). Characteristics of Covid-19 infection in Beijing. Journal of Infection,
$80(4)$,

401-406. https://doi.org/10.1016/j.jinf.2020.02.01 8

Virdasari, E., Arso, S. P., \& Fatmasari, E. Y. (2018). Analisis Kegiatan Pendataan Keluarga Program Indonesia Sehat Dengan Pendekatan Keluarga Di Pukesmas Kota Semarang (Studi Kasus Pada Pukesmas Mijen). Jurnal Kesehatan Masyarakat (E-Journal), 6(5), 52-64. Retrieved from https://ejournal3.undip.ac.id/index.php/j $\mathrm{km} /$ article/view/21977

Wulandari, J., \& Ernawati, M. (2018). Efek Iklim Kerja Panas Pada Respon Fisiologis Tenaga Kerja Di Ruang Terbatas. The Indonesian Journal of Occupational Safety and Health, 6(2), 207-215.

https://doi.org/10.20473/ijosh.v6i2.2017 .207-215

Young, L. M., Motz, V. A., Markey, E. R., Young, S. C., \& Beaschler, R. E. (2017). Recommendations for best disinfectant practices to reduce the spread of infection via wrestling mats. Journal of Athletic Training, 52(2), 82-88. https://doi.org/10.4085/1062-605052.1 .02 